\title{
Tipomorfologi Permukiman Kasepuhan Sinar Resmi, Kabupaten Sukabumi
}

\author{
Sari Mawaddahni \\ Magister Arsitektur, Universitas Brawijaya \\ Jl. MT. Haryono No. 165, Malang, Indonesia 65145.
}

\begin{abstract}
Abstrak
Kata kunci: kampung adat, genius loci, tipomorfologi, elemen ekistics, pelestarian

Kampung sebagai salah satu jenis permukiman, merupakan manifestasi dari aspek sosial budaya dari masing-masing kelompok masyarakat tersebut. Pada umumnya, suatu budaya diwariskan oleh leluhur secara turun temurun dari satu generasi ke generasi selanjutnya. Mengacu pada tiga unsur kebudayaan menurut Koentjoroningrat, permukiman Kasepuhan Sinar Resmi merupakan bentuk dari kebudayaan fisik. Mangunwijaya mengungkapkan, manusia memandang sebuah rumah tidak hanya sebagai tempat tinggal dan tempat bernaung, namun terdapat dimensi citra yang menyebabkan adanya pemaknaan pada bangunan serta ruang tempat tinggalnya. Kasepuhan Sinar Resmi merupakan salah satu kasepuhan yang termasuk dalam Kasepuhan Adat Banten Kidul. Bertitik tolak pada Genius Loci kawasan permukiman Kasepuhan Sinar Resmi yang penuh makna, maka dilakukan kajian mengenai tipomorfologi kawasan permukiman tersebut dengan identifikasi elemen ekistics. Dalam kajian ini, perumusan permasalahan mengenai kajian tipomorfologi pada pemukiman Kasepuhan Sinar Resmi adalah bagaimana tipologi dan morfologi kawasan permukiman Kasepuhan Sinar Resmi, ditinjau dari tatanan massa dan bentuk bangunannya secara makro, meso maupun mikro. Dari hasil kajian didapatkan empat buah jenis bangunan yang terdiri dari bangunan rumah tinggal dan fasilitas umum. Morfologi yang terjadi secara mikro, turut mempengaruhi identitas kawasan permukiman. Hasil kajian diharapkan dapat menjadi pertimbangan bagi pemerintah untuk upaya pelestarian sebagai kawasan cagar budaya.
\end{abstract}

Key words : traditional village, genius loci, typomorphology, ekistics elements, conservation

\section{Abstract}

Village is one type of settlement, as a manifestation of the socio-cultural aspects of each community group. Generally, a culture is passed down by an ancestral hereditary from one generation to the next. Referring to the three elements of culture according to Koentjaraningrat, Kasepuhan Sinar Resmi settlement is a form of physical culture. Mangunwijaya reveals, human view of a house not only as a place to live and shelter, but there is a dimension of the image that intensify the meaning of the building and the room where human lived. Kasepuhan Sinar Resmi is one of the Kasepuhan which is included in Kasepuhan Adat Banten Kidul. Started on the Genius loci of the meaningful settlement, a review of the typology of the settlement area is conducted with the identification of the ekistics elements. In this study, the formulation of problems on the study of typomorphology in Kasepuhan Sinar Resmi settlement is how typology and morphology of residential area of Kasepuhan Sinar Resmi, viewed from the mass order and the shape of the building in macro, meso and micro aspect. From the results of the study obtained four types of buildings consisting of residential buildings and public facilities. Morphology that occurs in building's facade, also influence the identity of the settlement area. The results of the study are expected to be a consideration for the government for conservation efforts as a cultural heritage area. 


\section{Tipomorfologi Permukiman Kasepuhan Sinar Resmi, Kabupaten Sukabumi}

Sari Mawaddahni

\section{PENDAHULUAN}

\section{Latar Belakang}

Kebudayaan adalah identitas dari sebuah bangsa, yang terbentuk mulai dalam lingkup terkecil seperti keluarga, desa, kampung, permukiman, hingga ke lingkup yang luas seperti perkotaan. Sejumlah masyarakat yang tinggal dalam wilayah yang sama, dengan batas-batas wilayah tertentu yang disepakati bersama oleh kelompok masyarakat tersebut dengan berbagai aspek yang melingkupi kesatuan hidupnya disebut sebagai kampung ${ }^{1}$. Kampung sebagai salah satu jenis permukiman, merupakan manifestasi dari aspek sosial budaya dari masing-masing kelompok masyarakat tersebut. Pada umumnya, suatu budaya diwariskan oleh leluhur secara turun temurun dari satu generasi ke generasi selanjutnya. Mendirikan rumah sebagai tempat bernaung dan melindungi diri dari alam dan pengaruh cuaca merupakan tradisi yang dijalankan oleh leluhur sejak jaman dahulu. Mengacu pada tiga unsur kebudayaan menurut Koentjoroningrat, permukiman Kasepuhan Sinar Resmi merupakan bentuk dari kebudayaan fisik. Mangunwijaya (1992) mengungkapkan bahwa seiring dengan berjalannya waktu, manusia memandang sebuah rumah tidak hanya sebagai tempat tinggal dan tempat bernaung, namun terdapat dimensi citra yang menyebabkan adanya pemaknaan pada bangunan serta ruang tempat tinggalnya ${ }^{2}$.

Indonesia merupakan negara dengan diversitas suku yang tersebar di seluruh wilayah kepulauan. Hal ini menimbulkan perbedaan kondisi fisik lingkungan antara permukiman satu dengan lainnya sehingga terbentuk berbagai jenis permukiman. Kondisi fisik ini mencakup perbedaan geologi, iklim, suhu, morfologi lingkungan, hidrologi dan lain sebagainya. Selain kondisi fisik, sebuah permukiman juga sangat bergantung pada perkembangan sosial budaya masyarakat, mencakup agama, kepercayaan, tradisi leluhur hingga faktor latar belakang sejarah. Dansby mengungkapkan bahwa tata ruang sebuah permukiman sangat bergantung pada pandangan hidup dari masing-masing individu, dimana hal ini berakar dari terjalinnya hubungan antar individu dalam sebuah keluarga, serta hubungan antara individu tersebut dengan individu lain dalam suatu lingkungan ${ }^{3}$.

Permukiman Kasepuhan Sinar Resmi yang berada di Desa Sirnaresmi, Kecamatan Cisolok, Kabupaten Sukabumi, Propinsi Jawa Barat, merupakan salah satu bentuk perkampungan tradisional yang masih bertahan hingga kini. Nilai-nilai tradisi leluhur yang berakar pada kehidupan rural agraris masih dipegang kuat oleh masyarakatnya. Kasepuhan Sinar Resmi merupakan salah satu kasepuhan yang termasuk dalam Kasepuhan Adat Banten Kidul. Bertitik tolak pada Genius Loci kawasan permukiman Kasepuhan Sinar Resmi yang penuh makna, maka dilakukan kajian mengenai tipomorfologi kawasan permukiman tersebut. Secara arsitektural, tipomorfologi permukimannya tipikal dengan arsitektur Sunda Lama. Dalam kajian ini digunakan pendekatan tipomorfologi untuk memahami pola tata ruang dan bentuk arsitektural beserta aspek-aspek dan faktor-faktor yang menjadi latar belakang dari terbentuknya permukiman Kasepuhan Sinar Resmi.

\section{Permasalahan}

Keberadaan permukiman Kasepuhan Sinar Resmi sebagai perkampungan adat dengan nilai tradisi leluhur yang masih dipertahankan hingga saat ini tidak lepas dari konsep bentuk dan filosofi dari arsitektur Sunda Lama. Dalam kajian ini, perumusan permasalahan mengenai kajian tipomorfologi pada pemukiman Kasepuhan Sinar Resmi adalah bagaimana tipologi dan morfologi kawasan permukiman Kasepuhan Sinar Resmi, ditinjau dari tatanan massa dan bentuk bangunannya secara makro, meso maupun mikro. 


\section{Tujuan}

Berdasarkan perumusan masalah terhadap kajian tipomorfologi permukiman Kasepuhan Sinar resmi, tujuan yang ingin dicapai adalah mengidentifikasi, menganalisis dan mendeskripsikan tipologi dan morfologi kawasan permukiman Kasepuhan Sinar Resmi, ditinjau dari tatanan massa dan bentuk bangunannya secara makro, meso maupun mikro. Adapun kontribusi kajian ini diharapkan dapat memberikan tambahan dalam khasanah pengetahuan sehingga dapat dipergunakan sebagai pertimbangan dalam upaya pelestarian perkampungan adat tersebut.

\section{METODE DAN PENELITIAN}

\section{Deskripsi Kawasan}

Masyarakat kasepuhan Sinar Resmi merupakan bagiandari komunitas Kasepuhan Banten Kidul, yakni kelompok masyarakat adat Sunda yang tinggal di sekitar Gunung Halimun, terutama di wilayah Kabupaten Sukabumi sebelah barat hingga ke Kabupaten Lebak, dan ke utara hingga ke Kabupaten Bogor. Kasepuhan menunjuk pada adat istiadat lama yang masih dipertahankan dalam kehidupan sehari-hari. Kasepuhan merupakan suatu himpunan dari banyak lembur (permukiman) dan kampung-kampung kecil dan besar yang terikat secara adat dan budaya4. Leluhur masyarakat Kasepuhan yang tinggal di TNGHS, awalnya berasal dari suatu kampung yang bernama Guradog (di daerah Bogor).

Selanjutnya anak cucu mereka menyebar ke daerah Lebak dan Sukabumi. Dikisahkan bahwa mereka memiliki hubungan yang erat dengan seorang Raja Sunda yang memelihara padi dari bagian tubuh Sri Pohaci (Dewi Padi) yang telah meninggal dunia. Sang Raja kemudian memelihara padi tersebut melebihi jenis tumbuhan lain, selayaknya memelihara seorang manusia. Dengan latar belakang tersebut, masyarakat kasepuhan menggantungkan hidupnya pada sektor pertanian de- ngan sistem huma sebagai sistem pertanian lokal yang diturunkan oleh karuhun (leluhur).

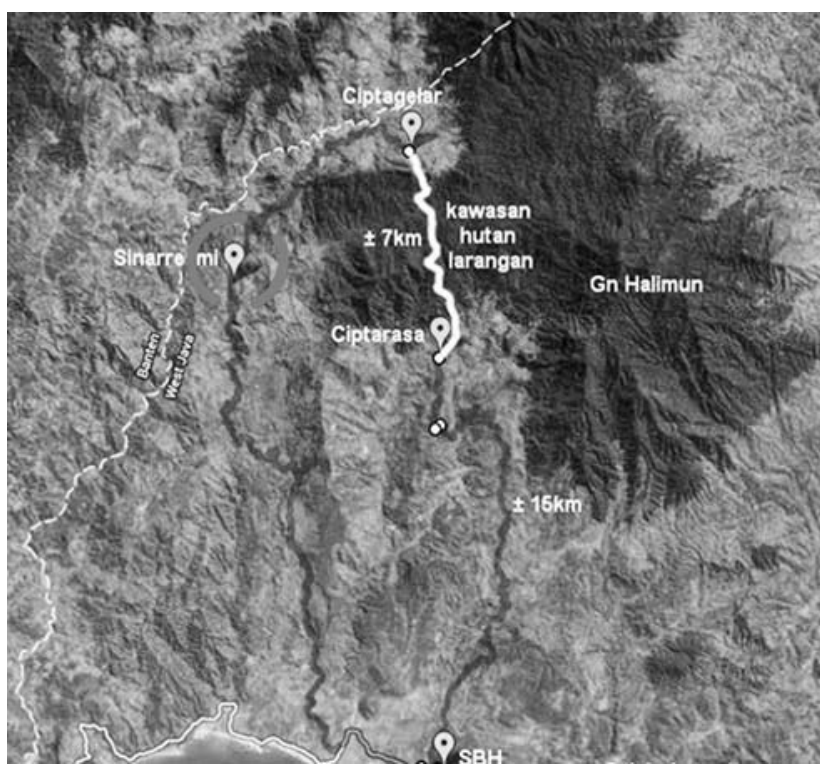

Gambar 1. Letak Permukiman Kasepuhan Adat Banten Kidul di Area Taman Nasional Gunung Halimun Salak (Sumber: www.budaya-sukabumi.blogspot.co.id)

\section{Kajian Pustaka}

Sebuah permukiman dalam suatu kawasan akan mengalami perubahan seiring dengan berjalannya waktu, terutama dalam bidang ekonomi, sosial, budaya, termasuk di dalamnya adalah bangunan sebagai artefak hasil wujud fisik sebuah kebudayaan. Perubahan kebutuhan hidup serta perkembangan teknologi dapat menjadi pemicu dari terjadinya perubahan ini. Studi mengenai tipologi dan morfologi merupakan sebuah pendekatan untuk melihat terjadinya perubahan baik dalam skala bangunan maupun kawasan. Tipologi dan morfologi merupakan satu cara pengkategorisasian di bidang ilmu arsitektur yang mempelajari bagaimana tipe-tipe dan bentuk bangunan. Analisis mengenai tipologi dan morfologi dapat dilakukan pada bangunan tunggal atau pada seluruh bangunan yang ada di suatu kawasan, dan bisa juga untuk memberikan tipe bentuk pada beberapa bangunan yang mempunyai fungsi yang sama5. Tipologi dan 


\section{Tipomorfologi Permukiman Kasepuhan Sinar Resmi, Kabupaten Sukabumi}

Sari Mawaddahni

morfologi juga merupakan komponen struktural dalam memahami makna suatu tempat atau Genius Loci. Menurut

Schulz, Genius Loci dapat merefleksikan keunikan dan kekhasan suatu tempat, yang membedakan satu tempat dengan tempat yang lain6.

\section{Tipologi Dalam Arsitektur}

Studi tentang tipologi menyangkut studi tentang tipe, dengan mengkaji adanya kesamaan ciri khas secara formal dari sekelompok obyek, atau juga dapat berarti sebagai studi tentang pengelompokan obyek (sebagai model) melalui kesamaan struktur. Makna yang terkandung dalam tipologi tidak hanya berkaitan dengan geometri fisik, tetapi juga yang berkaitan dengan kondisi nyata, mulai dari aktifitas sosial hingga konstruksi bangunan merupakan makna dari struktur formal ${ }^{7}$.

Tipologi dapat dijabarkan sebagai suatu bentuk klasifikasi objek, struktur atau spesimen dengan membagi populasi yang diamati kedalam rangkaian teoritik atau seri kelompok dan subnya berdasarkan pertimbangan atribut kualitatif, kuantitatif, morfologi, formal, teknologi, dan fungsi ${ }^{8}$.

Sebagai suatu perangkat fungsi dan instrumental, tipologi dapat diterima dan penting dalam suatu ketentuan yang dipahami dalam komunitas arsitektur ${ }^{9}$. Lebih lanjut, Sulistijowati dalam Ramadanta juga menyebutkan teori milik Gianugo Polesello bahwa tipologi dalam arsitektur dapat berasal dari bentuk arsitektural yang disederhanakan (given types), menjadi bentuk geometrik. Proses ini dapat ditemukan melalui sejarah terbentuknya arsitektur tersebut, maupun dari hasil penemuan yang baru ${ }^{10}$.

Aspek yang menjadi kriteria pengelompokan (tipologi) dalam arsitektur menurut Sulistijowati dalam Suharjanto dapat dibagi dalam kelas-kelas, klasifikasi ataupun kelompok berdasarkan ${ }^{11}$ :
1. Fungsi (meliputi penggunaan ruang, struktural, simbolis);

2. Geometrik (meliputi bentuk, prinsip tatanan); dan

3. Langgam (meliputi periode, lokasi atau geografi, politik atau kekuasaan, etnik dan budaya).

Tipe seringkali digunakan untuk menjelaskan bentuk keseluruhan, struktur, atau karakter dari suatu bentuk atau objek tertentu. Ditinjau dari objek bangunan, tipologi terbagi atas tiga hal pokok, yaitu site (tapak) bangunan, form (bentuk) bangunan dan organisasi bagian-bagian bangunan tersebut ${ }^{12}$. Sebagai contoh untuk menganalisis tipe dari suatu bangunan, dapat dilakukan dengan berbagai cara. Menurut Moneo, analisis tipologi dibagi menjadi 3 cara yaitu:

a. Menggali sejarah untuk mengetahui ide awal dari suatu komposisi atau dengan kata lain mengetahui asal usul dari suatu objek kejadian.

b. Mengetahui fungsi suatu objek.

c. Mencari bentuk sederhana suatu bangunan berdasarkan bentuk dasar atau sifat dasarnya.

\section{Morfologi Dalam Arsitektur}

Secara harfiah, morfologi diartikan sebagai kajian tentang bentuk. Morfologi adalah studi tentang bentuk. Studi mengenai morfologi dimulai pada masa Renaissance, yaitu pada masa ditemukannya daerah-daerah baru dengan flora dan fauna yang sangat beragam dan mengarah pada bidang Biologi7. Pada perkembangan selanjutnya, studi morfologi tidak hanya menemukan klasifikasi dari bentuk dan struktur suatu obyek, tetapi lebih ke arah pemahaman tentang evolusi dan transformasi (metamorfosa). Ronald dalam Setyabudi berpendapat bahwa dalam kajian tentang morfologi terdapat aspek perubahan bentuk, hubungan, metamorfosis dan struktur dari sebuah 
objek $^{13}$. Perubahan terjadi melalui proses evolusi atau modifikasi, dan pada umumnya terjadi dalam jangka waktu yang sangat lama. Bentuk dasar banguan dapat ditelusuri dengan mengklasifikasikan bentuk- bentuk organik menurut tipe dan aturannya.

Kajian mengenai morfologi pada bangunan arsitektur maupun kawasan atau kota bertujuan untuk menemukan bentuk dasar baik perubahan bentuk, hubungan, metamorfosis dan struktur dari sebuah objek bangunan maupun kawasan ataupun kota. Kajian mengenai morfologi tidak hanya melihat secara fisik perubahan bentuk yang terjadi akan tetapi yang lebih penting adalah terekamnya serangkaian proses terjadinya perubahan dan alasan atau makna yang mendasari adanya perubahan tersebut. Perubahan ini bisa menggambarkan adanya perubahan ide atau makna dalam sejarah. Perubahan yang terjadi dapat disebabkan karena berbagai alasan, seperti perubahan dimensi, pemotongan atau pembesaran, penambahan ruang atau bentuk, perubahan warna dan susunan serta perubahan yang diakibatkan penggunaan material dan bahan yang berbeda dari keadaan semula.

Terbentuknya sebuah permukiman dipengaruhi oleh beberapa faktor yang secara keseluruhan dapat dilihat unsur-unsur ekistiknya. Genius Loci dapat diidentifikasi dari struktur dan identitas sebuah tempat. Dalam melihat Genius Loci dari permukiman Kasepuhan Sinar Resmi, digunakan teori ekistic pada pola permukimannya yang terdiri dari14: 1] Natural (Fisik Alami), 2] Man (Manusia), 3] Society, 4] Shell dan 5] Network (Jaringan). Pada pola permukiman tradisional, dapat ditemukan pola atau tatanan yang berbeda- beda sesuai dengan tingkat kesakralannya atau nilai-nilai adat dari suatu tempat tertentu. Hal tersebut memberikan pengaruh cukup besar dalam pembetukan suatu lingkungan hunian atau permukiman adat ${ }^{15}$.
Dalam melihat perkembangan dan perubahan di permukiman Kasepuhan Sinar Resmi, digunakan teori milik Habraken (1987) yang mengungkapkan lebih spesifik bahwa terdapat 3 aspek yang membentuk satu kesatuan sistem untuk melihat transformasi suatu hunian yaitu ${ }^{15}$ :

1. Sistem spasial (spatial system), yaitu berbagai aspek tolok ukur yang berkaitan dengan organisasi ruang atau ruang yang mencakup ruang, orientasi ruang dan pola hubungan ruang (pola spasial ruang).

2. Sistem fisik (physical system) yaitu berbagai aspek tolok ukur yang berkaitan dengan konstruksi dan penggunaan material-material yang digunakan dalam mewujudkan suatu fisik bangunan. Sistem ini mencakup hal-hal yang berkaitan dengan struktur konstruksi atap, dinding, lantai.

3. Sistem model (stylistic system) adalah berbagai aspek tolok ukur yang berkaitan dengan style langgam yang mewujudkan bentuk. Sistem ini meliputi fasade, bentuk pintu dan jendela, serta unsur- unsur lain baik di dalam maupun diluar bangunan.

\section{HASIL PEMBAHASAN}

Aspek Fisik Secara Makro

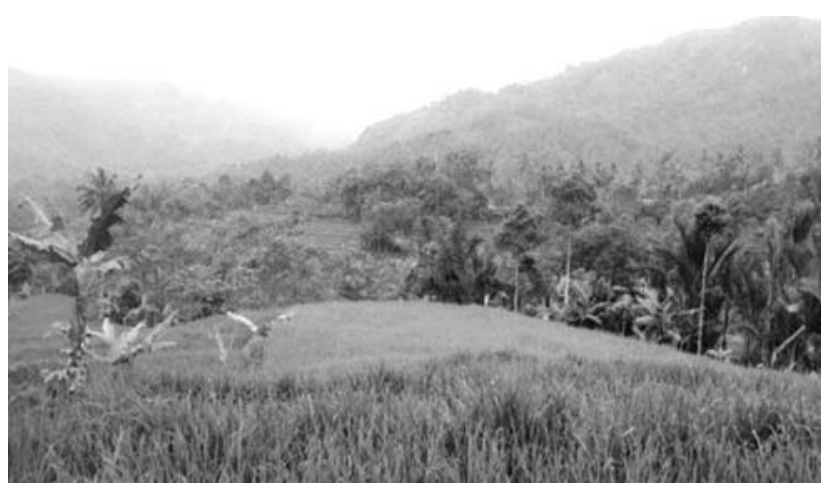




\section{Tipomorfologi Permukiman Kasepuhan Sinar Resmi, Kabupaten Sukabumi}

Sari Mawaddahni

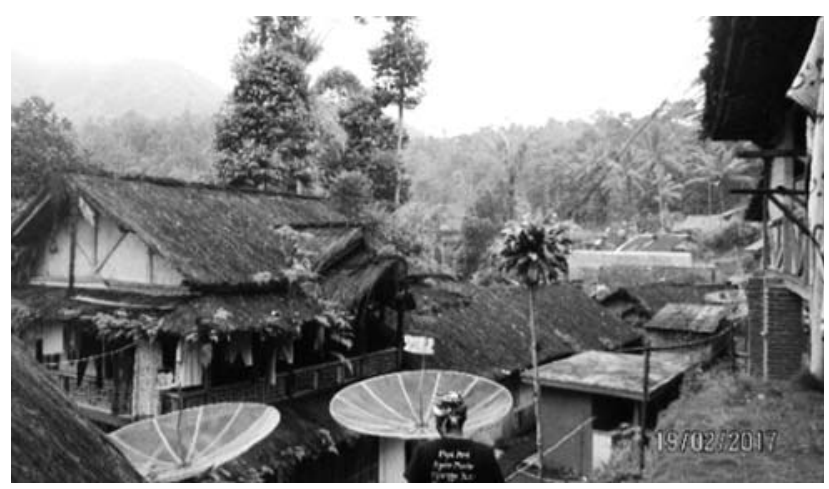

Gambar 2. Kondisi lahan berkontur pada kawasan permukiman dan persawahan (Sumber: Dokumentasi Pribadi)

\section{Alam}

Bentang alam dan kondisi geografis di kawasan kasepuhan sangat berpengaruh terhadap pola tata massa bangunan. Secara umum kondisi kawasan permukiman berupa lahan yang berkontur, sehingga tata massa bangunan juga mengikuti pola kontur lahan yang berbukit sebagai bentuk adaptasi terhadap lingkungan sekitarnya. Dengan kondisi lahan yang berkontur, maka persawahan yang ada di area permukiman menggunakan sistem terasering. Hal ini justru mendukung keberlangsungan kegiatan agraris masyarakat, karena dengan kondisi lahan berkontur akan memudahkan pengairan atau sistem irigasi pada area persawahan.

Bentang alam juga menjadi pembatas zona sakral dan profan bagi masyarakat permukiman. Ketentuan ini merupakan ajaran warisan leluhur yang tidak boleh dilanggar oleh masyarakat kasepuhan. Aturan tersebut berupa zoning pada wilayah hutan dengan pembagian sebagai berikut:

a. Hutan Tua (Leuweung Kolot), hutan asli yang masih rimbun, tidak boleh dieksploitasi.

b. Hutan Titipan/Kramat (leuweung Titipan), hutan Kramat yang harus dijaga oleh setiap orang dan tidak boleh digunakan tanpa seijin sesepuh girang, memungkinkan digunakan hasil hutannya bila ada wangsit dari leluhur.

c. Hutan Sempalan/bukaan (leuweung Sampalan), hutan bukaan yang boleh dieksploitasi untuk ladang, menggembalakan ternak, mencari kayu bakar dan ditanami berbagai tanaman kayu dan buah-buahan yang hasilnya bisa dimanfaatkan oleh masyarakat.

\section{Naungan}

Secara makro, pola permukiman masyarakat kasepuhan Sinar Resmi merupakan permukiman dengan pola memusat (aggromerated rural settlement) berupa kampung (village) yang terdiri atas lebih dari 40 buah rumah. Pola permukiman di kawasan ini tergolong dapat juga digolongkan sebagai pola permukiman mengantong yang terbentuk oleh jalan yang memagarnya. Berdasarkan istilah lokal, pola perkampungan ini adalah pola perkampungan Kuda sela, yakni perkampungan yang berada di punggung gunung, dimana pada bagian lembah terdapat permukiman lain. Pada permukiman Kasepuhan Sinar Resmi, terdapat dua macam pola pemrukiman yang terbentuk. Pertama adalah pola permukiman yang memusat dengan tata massa menyesuaikan kontur lahan yang berbukit, dan yang kedua adalah pola permukiman yang tumbuh secara linier mengikuti perkembangan jalan.

\section{Sirkulasi}

Secara umum aksesibilitas menuju kawasan permukiman ini cukup mudah karena sudah dapat dilalui oleh kendaraan baik roda dua maupun empat. Kondisi jalan kendaraan roda 2 dan 4 berupa jalan aspal, sedangkan untuk jalan lingkungan berupa jalan makadam atau tanah. Lebar jalan kendaraan \pm 5 meter, sedangkan jalan lingkungan \pm 1.2 meter. 
LOCAL WISDOM, Vol. 9 No. 1 Januari 2017

Local Wisdom Scientific Online Journal

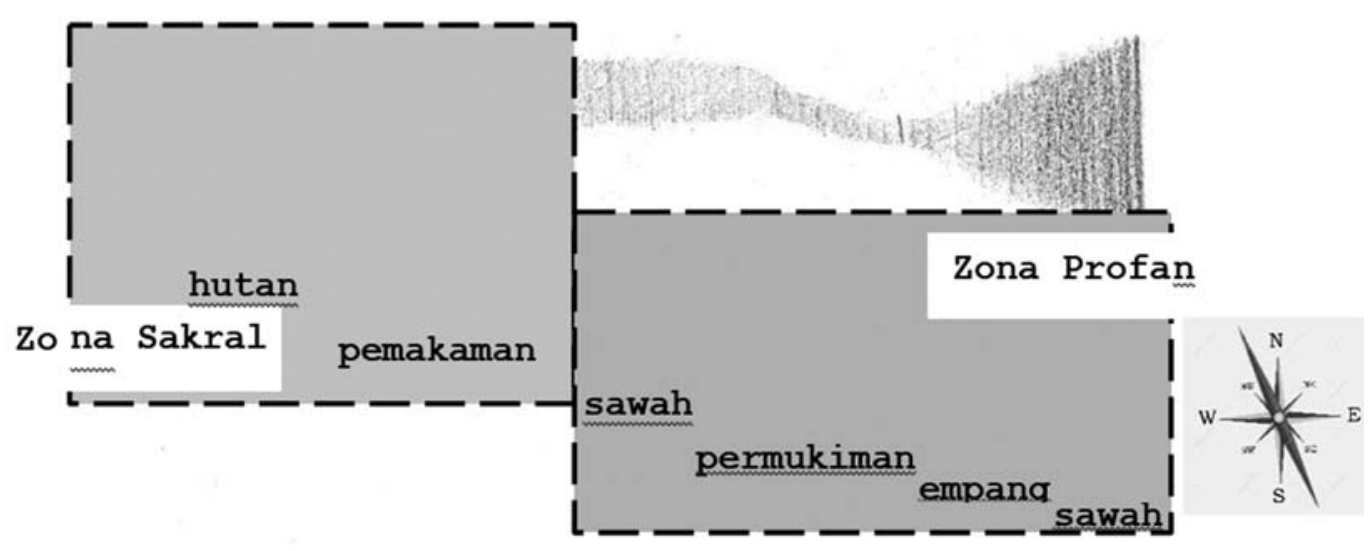

Gambar 3. Aturan leluhur mengenai zoning kawasan permukiman

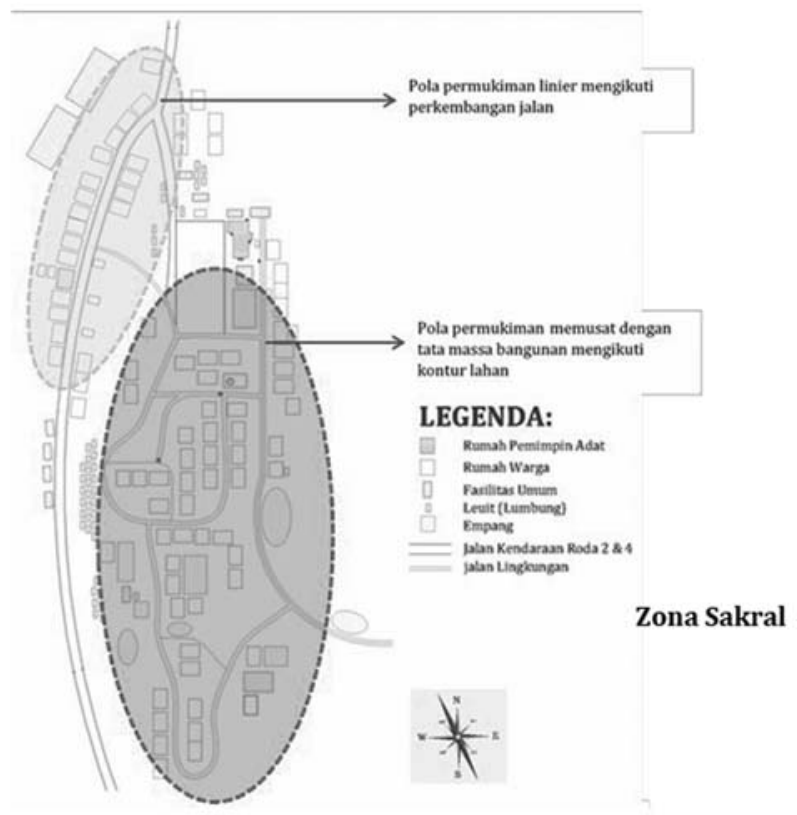

Gambar 4. Layout permukiman Kasepuhan Sinar Resmi (Hasil Analisa, 2017)

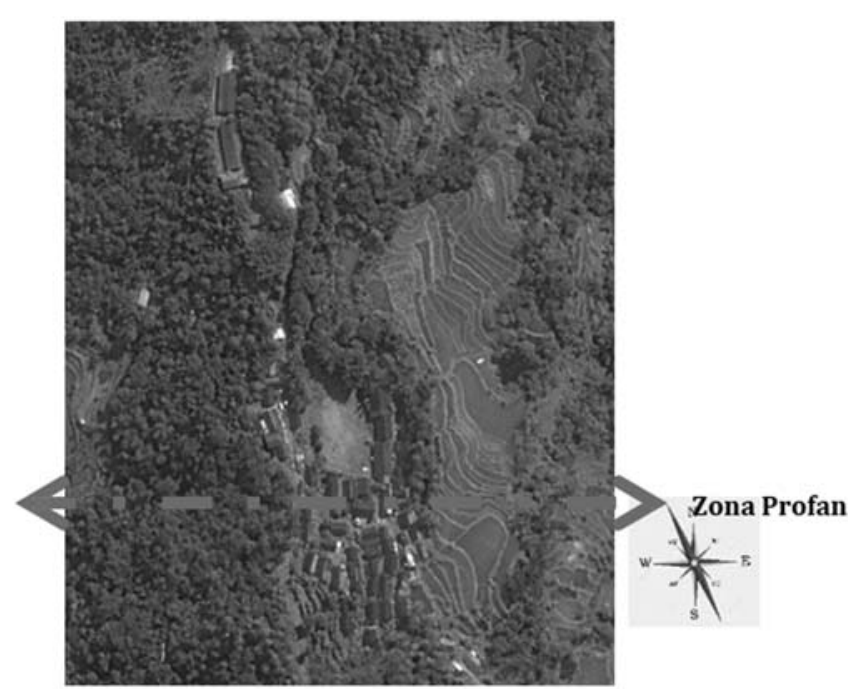

Gambar 5. Potongan melintang kawasan permukiman (Diolah dari Google earth) 
Tipomorfologi Permukiman Kasepuhan Sinar Resmi, Kabupaten Sukabumi

Sari Mawaddahni
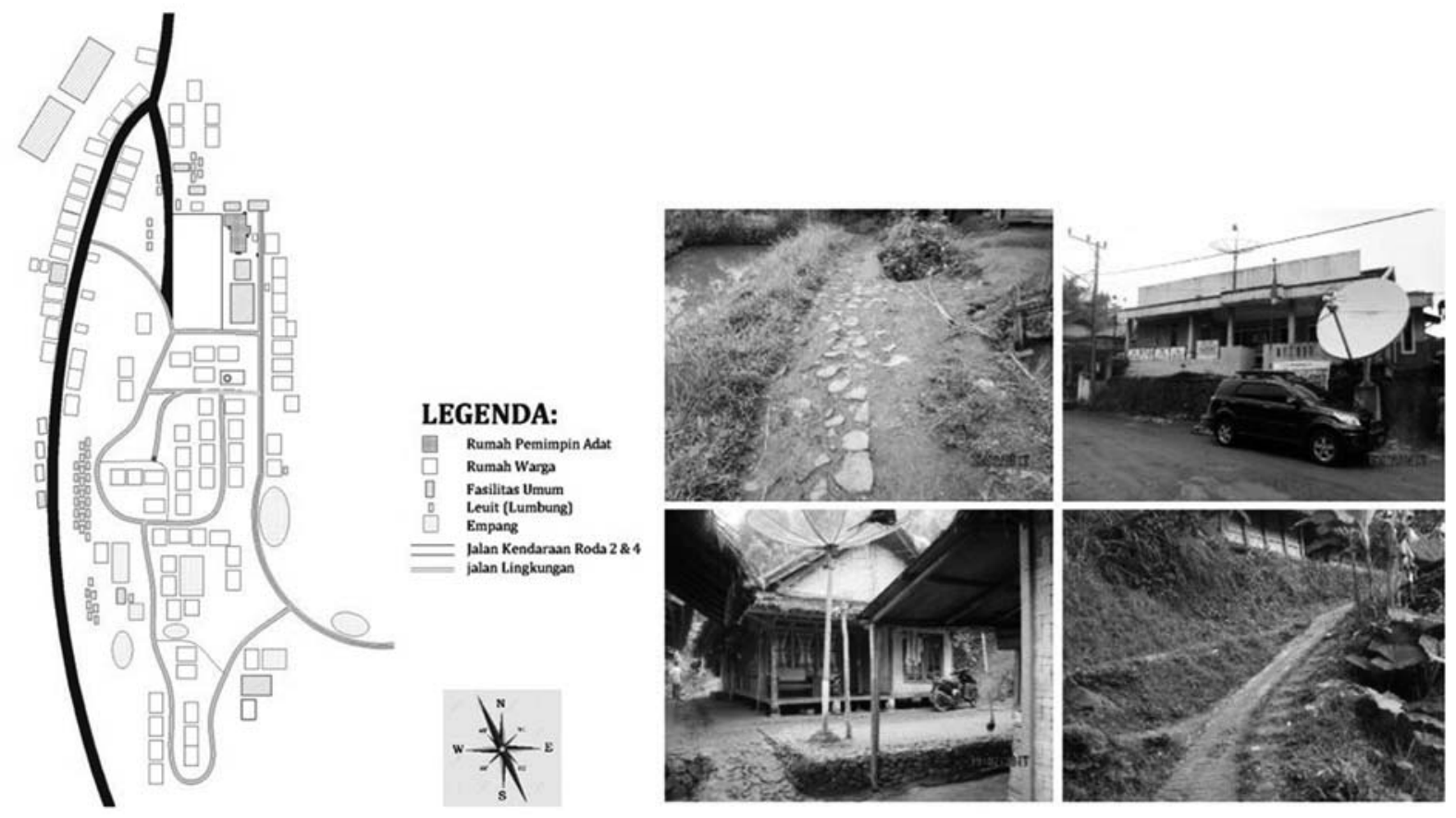

Gambar 6. Kondisi jalan lingkungan dan jalur kendaraan roda 2 dan 4

(Sumber: Dokumentasi pribadi, 2017)

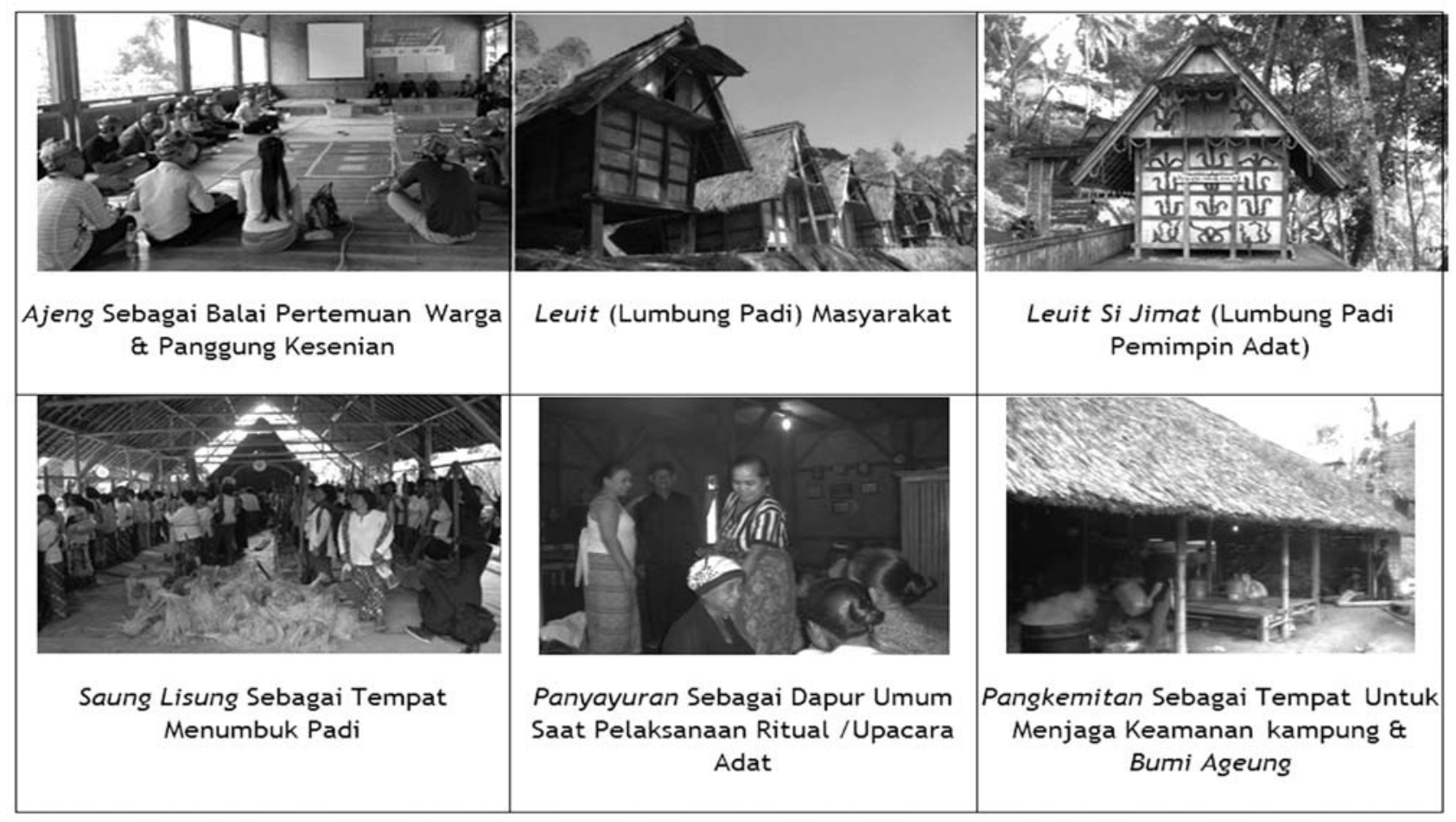

Gambar 7. Bangunan fasilitas umum di kawasan permukiman 


\section{Aspek Fisik Secara Meso}

Aspek yang akan dibahas pada sub bab ini adalah aspek fisik secara meso yang mencakup sarana dan prasarana yang terdapat pada permukiman. Secara meso, permukiman memusat pada rumah pemimpin adat yang berada di dekat pintu masuk kawasan permukiman. Rumah pemimpin adat terletak berdekatan dengan beberapa fasilitas umum seperti balai kesenian, balai pertemuan, pos jaga, dapur umum dan masjid. Pada permukiman Kasepuhan Sinar Resmi, masing- masing bangunan fasilitas umum memiliki fungsi tertentu.

\section{Aspek Fisik Secara Mikro}

Aspek fisik secara mikro membahas mengenai letak bangunan, bentuk, tata ruang dalam serta material rumah di permukiman Kasepuhan Sinar Resmi.

\section{Letak Bangunan}

Rumah masyarakat kasepuhan tipikal dengan arsitektur Sunda Lama abad ke-16. Ciri-ciri utama dari bentuk arsitektur ini adalah rumah panggung dengan dinding kayu atau anyaman bambu, dan atap ijuk. Bangunan warga terletak memusat dengan orientasi ke arah rumah pemimpin kasepuhan, sesuai kontur lahan, ataupun di tepi jelan dengan orientasi menghadap ke jalan. Rumah pemimpin adat tidak terletak di kontur tertinggi, namun untuk menunjukkan status sosialnya, rumah pemimpin adat dibuat lebih tinggi dibandingkan dengan rumah warga biasa dengan adanya penambahan tangga setinggi \pm 1 . . Ada kepercayaan kosmologis yang dianut oleh masyarakat kasepuhan, yakni semua pintu masuk baik rumah tinggal maupun lumbung berada di arah utara-selatan. Untuk rumah- rumah warga yang tidak berorientasi ke arah utara - selatan sehingga pintu masuk tidak berada pada arah tersebut akibat menyesuaikan dengan kondisi kontur lahan, disiasati dengan menambahkan bukaan di seluruh sisi dinding rumah berupa pintu atau jendela. Arah selatan dipercaya sebagai tempat bersemayamnya Dewi Padi (Dewi Sri). Akan tetapi terdapat alasan logis dibalik tradisi tersebut, yaitu agar cahaya matahari serta udara dapat masuk ke segala penjuru rumah, sehingga rumah beserta penghuninya tetap mendapatkan udara yang bersih dan sehat.
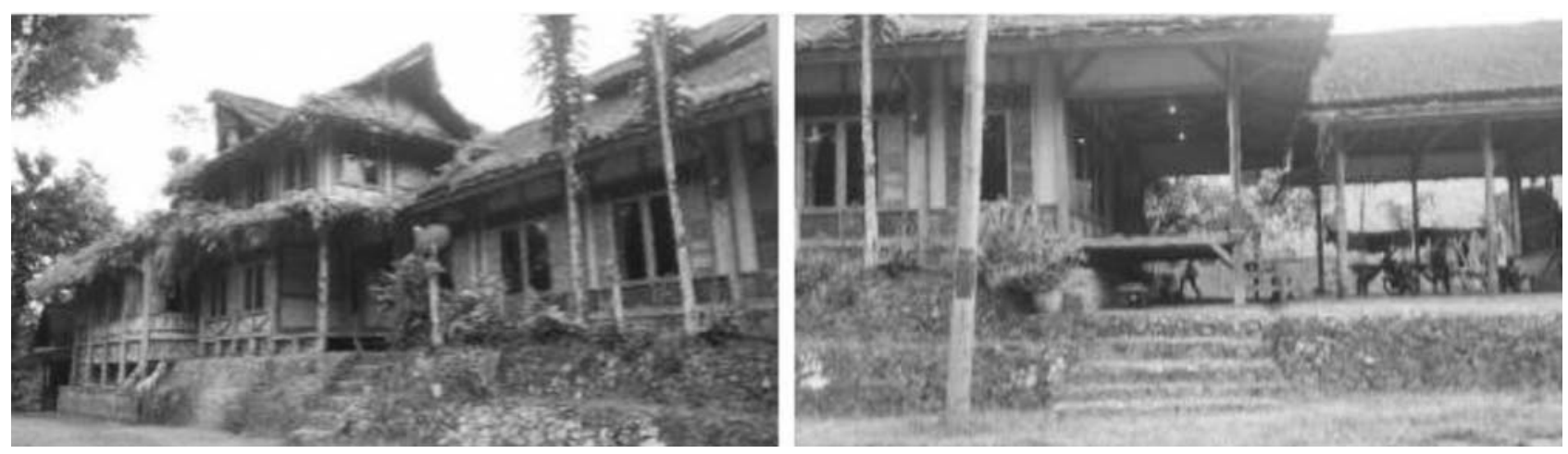

Gambar 8. Peninggian lantai rumah pada rumah pemimpin kasepuhan 


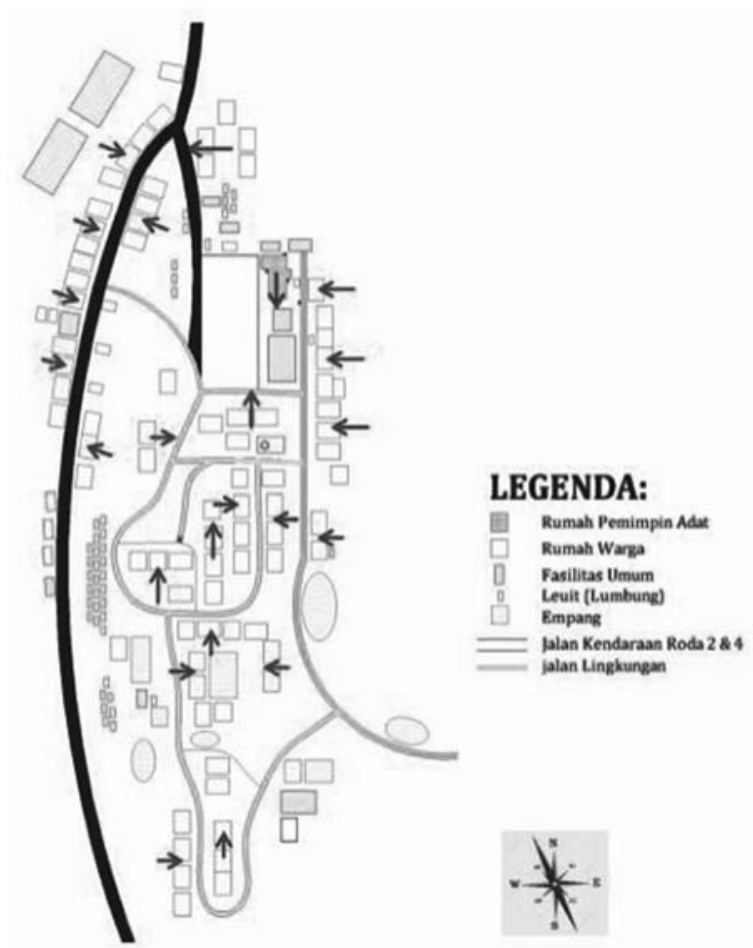

Gambar 9. Orientasi arah hadap bangunan (Sumber: Hasil analisis, 2017)

Dengan adanya lahan pertanian yang mengelilingi kawasan permukiman, diikuti oleh banyaknya lumbung padi yang juga menjadi simbol kemandirian setiap keluarga atau orang dewasa yang belum menikah. Lumbung diletakkan di dekat sawah garapan jauh dari permukiman untuk menghindari merembetnya api ke permukiman jika terjadi kebakaran. Semua lumbung padi berderet dan memiliki arah orientasi utara-selatan.

\section{Bentuk Bangunan}

Rumah masyarakat kasepuhan tipikal dengan arsitektur Sunda Lama abad ke-16. Ciri-ciri utama dari bentuk arsitektur ini adalah rumah panggung dengan dinding kayu atau anyaman bambu, dan atap ijuk. Ada kepercayaan kosmologis tersendiri yang dipercaya oleh masyarakat, bahwa
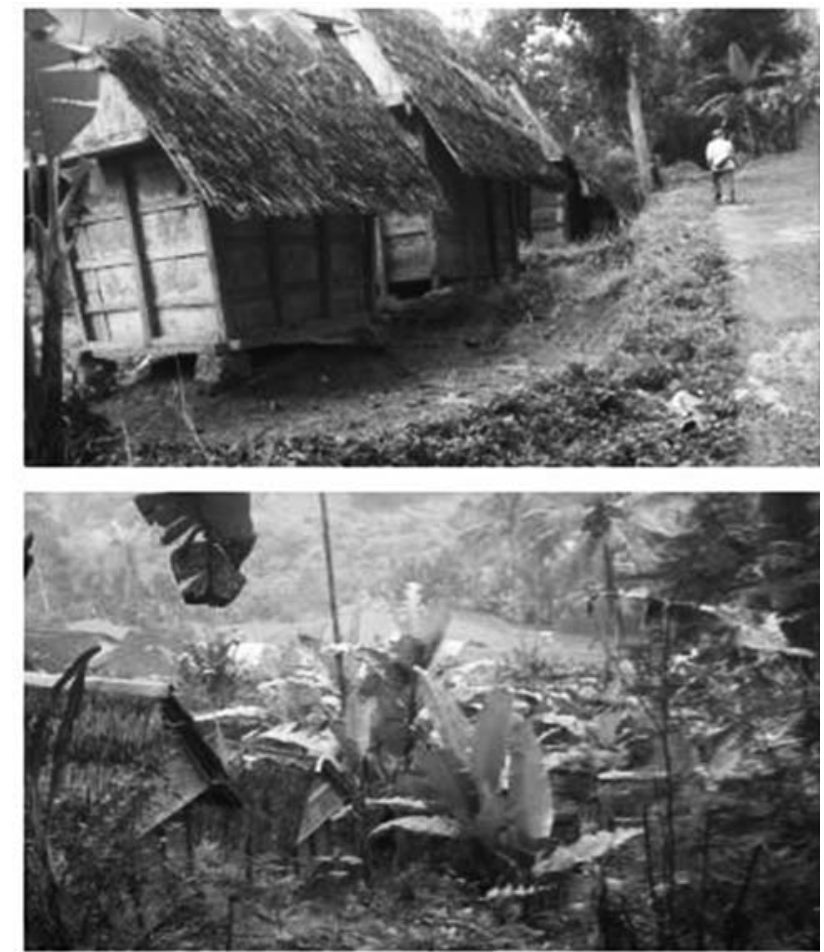

Gambar 10. Kelompok Leuit di kawasan permukiman (Sumber: Dokumentasi pribadi, 2017)

material yang digunakan dalam bangunan tidak boleh terbuat dari tanah karena seakan-akan mengubur pemiliknya. Fungsi secara simbolik didasarkan pada kepercayaan bahwa dunia terbagi atas tiga dunia, yakni dunia bawah, tengah dan atas. Dunia tengah merupakan pusat alam semesta dan manusia menempatkan diri sebagai pusat alam semesta, karena itulah tempat tinggal manusia harus terletak di tengah-tengah, tidak ke dunia bawah (bumi) dan atas (langit). Dengan demikian, rumah tersebut harus memakai tiang yang berfungsi sebagai pemisah rumah secara keseluruhan dengan dunia bawah dan atas. Tiang rumah juga tidak boleh terletak langsung di atas tanah, oleh karena itu harus diberi alas yang berfungsi memisahkannya dari tanah, yaitu berupa batu yang disebut umpak atau tatapakan. 


\section{a. Pondasi}

Jenis pondasi yang digunakan adalah pondasi umpak, ketinggian dari tanah 40-60 cm. Pondasi umpak juga sebagai alas bagi bertumpunya tiang rumah. Batu untuk pondasi berbentuk lesung (lisung), yaitu batu berbentuk balok yang berdiri tegak dengan permukaan pada sisi atas lebih kecil daripada permukaan sisi bawah. Pondasi umpak ini menyebabkan rumah panggung sebagai konstruksi yang tahan gempa, karena telapak pondasi akan bergerak dinamis jika ada ge,rakan tektonik. Ruang yang berada di bawah lantai rumah (kolong) dimanfaatkan sebagai tempat penyimpanan kayu bakar, alat pertanian, maupun kandang ternak (ayam, itik, ikan). Pada lelemahan, warga menggunakan pondasi umpak dengan teknik pemasangan dikubur sebagian di dalam tanah, sedangkan bahannya terbuat dari batu kali. Masyarakat memiliki pandangan yang sama tentang makna simbolik pada lelemahan, yaitu kematian.

Bentuk rumah panggung sebagai bentuk dari kearifan lokal masyarakat memiliki fungsi ekologis antara lain: [1] fungsi tanah sebagai bidang resapan air tetap terjaga; dan [2] terjadi cross air ventilation pada ruang kolong sehingga tercapai kenyamanan suhu pada malam (masuknya udara hangat kedalam rumah) dan siang hari (pertukaran udara panas dengan udara yang sejuk). Kondisi kontur lahan pada permukiman kasepuhan berkontur dan tidak rata karena berada di kawasan pegunungan dan perbukitan. Hal ini disikapi oleh masyarakat kasepuhan dengan pola tata massa bangunan yang menyebar sesuai bentuk kontur.

b. Dinding

Pada dinding, warga menggunakan bilik, triplek dan papan, sedangkan lantainya dari talupuh, papan serta bilik. Bahan yang digunakan pada dinding dan lantai berasal dari bambu dan kayu. Penyelesaian atau sentuhan akhir (finishing touch) pada dinding terlihat sederhana, yakni dengan vernis atau cat kayu, sedangkan pada lantai dibiarkan polos sesuai aslinya. Untuk mengurangi rasa dingin di malam hari, warga menggunakan tikar yang biasa disebut samak, terbuat dari daun pandan atau plastik. Konstruksi sambungan kayu-bambu pada dinding, lantai, atap dan langit-langit menggunakan teknik sambungan bibir miringberkait, bibir lurus-berkait, penlubang dan diperkuat dengan paku, pasak, ikatan tali atau ijuk sesuai kebiasaan mereka. Pada rumah warga tidak ditemukan letak pintu depan yang segaris lurus dengan pintu belakang. Hal tersebut didasarkan pada pandangan kosmik warga tentang lalu lintas rejeki dan keberuntungan.

\section{c. Atap}

Berdasarkan bentuknya, atap pada rumah warga ksepuhan Sinar Resmi merupakan atap jenis pelana, atau disebut sebagai Suhunan Lurus (Suhunan Jolopong). Dalam bahasa Sunda, istilah Jolopong memlliki arti tergolek lurus. Kedua bidang atap dipisahkan oleh jalur suhunan yang terletak di bagian tengahnya. Bentuk atap suhunan lurus (suhunan jolopong) merupakan bentuk dasar atap rumah adat Sunda, dan hampir semua rumah di tatar Sunda menggunakan bentuk atap jenis ini.

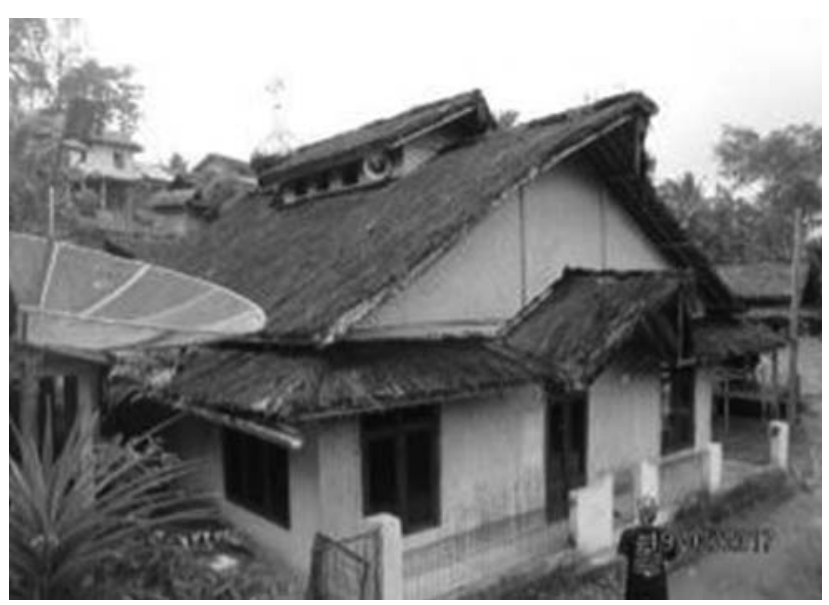



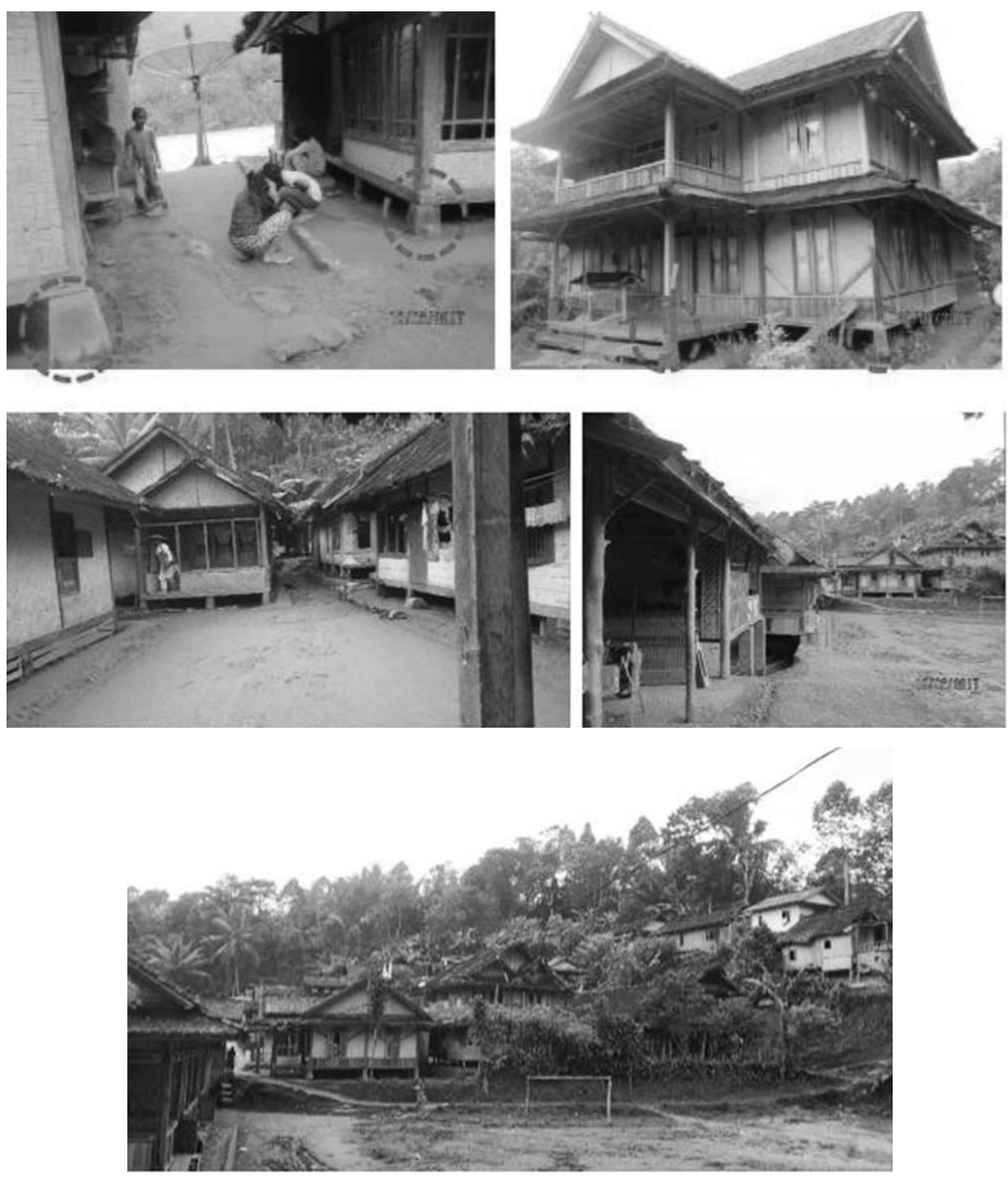

Gambar 11. Atas: Bentuk pondasi umpak; tengah: penggunaan kayu dan anyaman bambu sebagai penutup dinding; bawah: bentuk atap pelana dengan penutup atap dari rumbia

(Sumber: Dokumentasi pribadi, 2017) 


\section{Tata Ruang Dalam}

Rumah masyarakat kasepuhan harus memiliki tiga ruang penting yaitu pangdaringan, hawu, dan sepen.

a. Pangdaringan, berbentuk segi empat, terbuat dari bahan kayu, dan ditutupi tirai 'kasang' (pintu dari kayu)

b. Tungku yang bagian tengahnya agar api dapat bekerja dengan baik. Letaknya di goah (dapur Hawu, berbentuk segi empat, dibuat dari bahan semen yang dicetak dan dilubangi) dan di atasnya terdapat rak dari kayu untuk meletakkan perlengkapan dapur maupun bibit dan alat pertanian.

c. Sepen, berfungsi sebagai ruang tidur, dibatasi dengan dinding kayu dengan 'kasang' sebagai tirai.

Organisasi ruang pada rumah panggung terdiri dari 3 (tiga): tepas imah, tengah imah dan pawon. Tepas imah (depan) merupakan daerah laki-laki, karena aktifitasnya cenderung dilakukan oleh lakilaki, tengah imah (tengah) menjadi daerah umum, karena laki-laki dan perempuan dapat melakukan aktifitas bersama-sama, sedangkan pawon (belakang) merupakan daerah perempuan, karena seluruh aktifitasnya dilakukan oleh perempuan.

Pembagian daerah laki-laki dan perempuan tersebut didasarkan pada fungsi ruang dan jenis aktifitasnya, sedangkan pembagian depan, tengah dan belakang didasarkan pada tata letak ruang. Wanita menempati daerah belakang dan dalam, sedangkan laki-laki berada pada daerah depan dan samping. Bagian depan sebagai daerah laki-laki, karena laki-laki bersifat di luar, terlibat politik dan hubungan eksternal. Tengah bersifat netral, terbuka bagi laki-laki dan perempuan, sedangkan belakang merupakan daerah perempuan, padaringan dan goah khusus untuk perempuan dan menjadi daerah terlarang bagi laki-laki.

Masyarakat Kasepuhan Sinar Resmi merupakan masyarakat rural agraris yang masih menjunjung tinggi tradisi dan ajaran leluhur yang telah diwariskan kepada generasi-generasi penerusnya. Padi tidak dianggap sebagai komoditas pangan maupun perdagangan, namun memiliki makna sebagai sumber kehidupan yang disakralkan keberadaannya, baik di area pertanian, di lumbung, maupun di dalam rumah. Sebagai sesuatu yang disa-

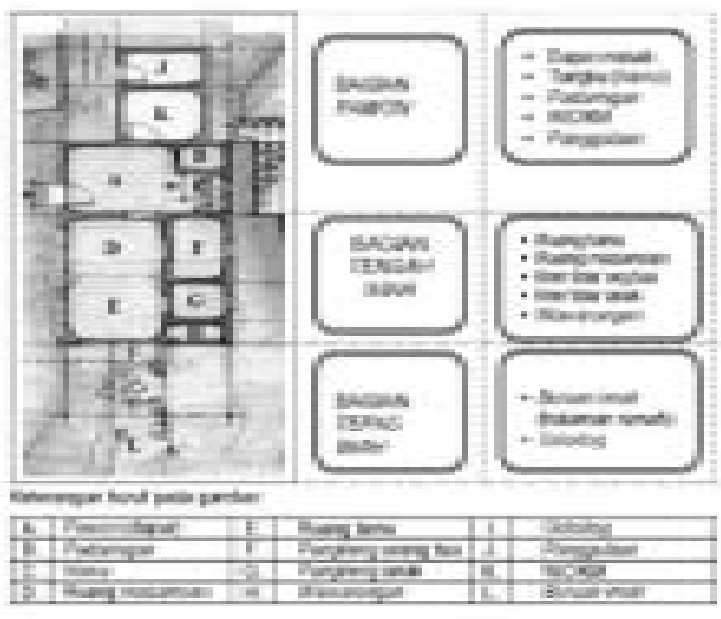

Gambar 12. Pola tata ruang pada bangunan rumah tinggal warga (Sumber: Nuryanto \& Machpudin, 2008)

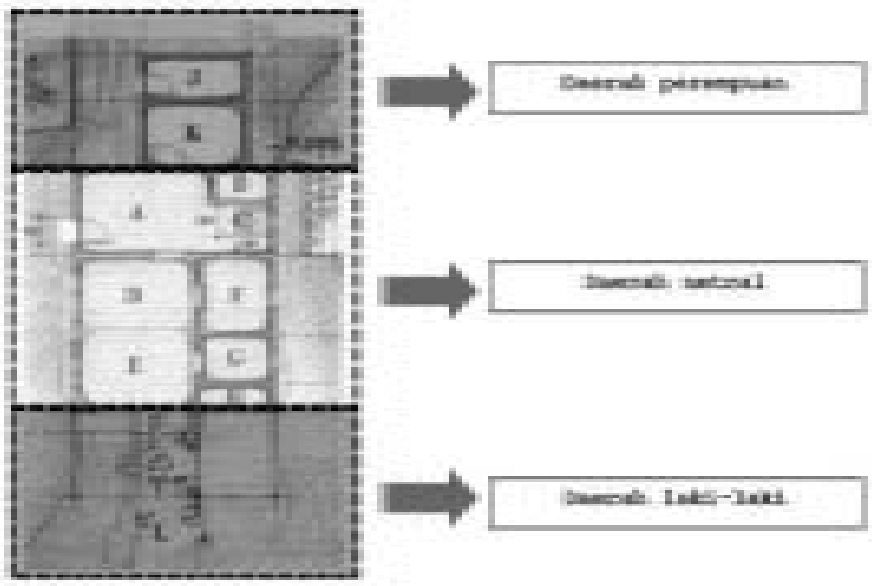

Gambar 13. Zoning berdasarkan gender pada bangunan rumah tinggal warga (Sumber: Diolah dari Nuryanto \& Machpudin, 2008) 


\section{Tipomorfologi Permukiman Kasepuhan Sinar Resmi, Kabupaten Sukabumi}

Sari Mawaddahni

kralkan, padi memiliki ruang penyimpanan tersendiri di dalam rumah yang disebut dengan padaringan. Hanya istri atau anak perempuan dari pemilik rumah yang boleh memasuki tempat tersebut. Wanita selain pemilik rumah tidak diperbolehkan untuk memasuki padaringan. Saat mengambil beraspun, ada aturan khusus yang harus dijalankan, yakni dengan memakai baju adat berupa kebaya dan kain panjang (sinjang).

Secara umum, permukiman Kasepuhan Sinar Resmi dibentuk oleh beberapa elemen, yakni elemen alam, naungan, sirkulasi, manusia dan masyarakat. Elemen-elemen tersebut dapat dikategorikan sebagai berikut:

Tabel 1. Tipologi Elemen Pembentuk Kawasan Permukiman

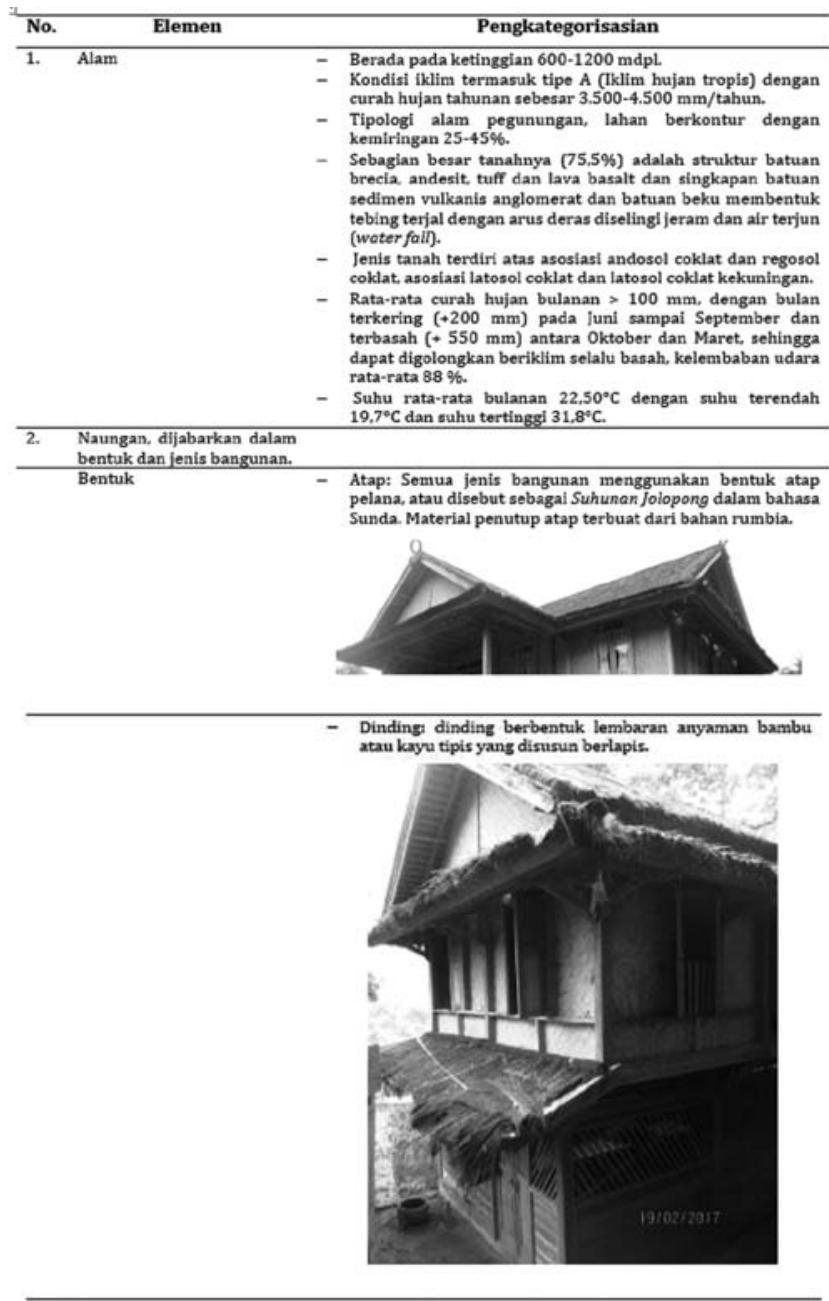

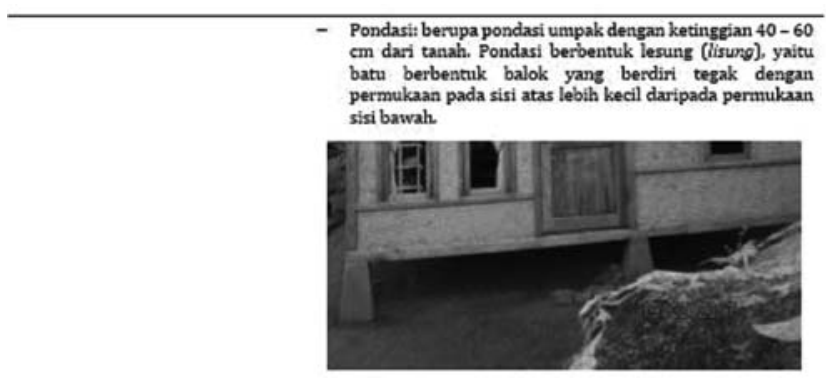

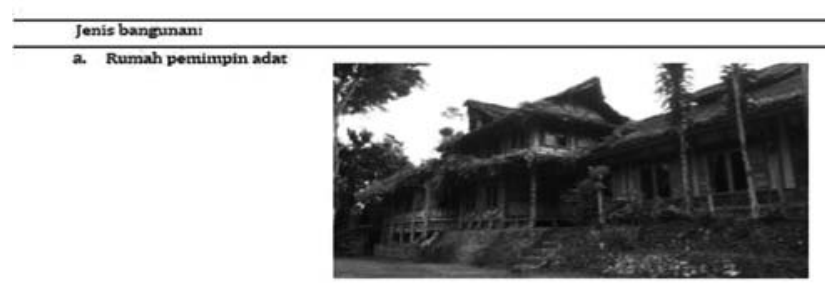

- Bangunan rumah tingzal pemimpin adat kasepuhan rumah yang cukup tineal (1.2 meter). Unouran rumanh sangat luas, karema selain sebagal bangunan rumah tingzal juga sebagal cempat menginap tamu, pertemuan warga maupun Bangunan rumah tingeal pemimpin adat juga sebagai pusat

- Bangunan fasilitas umum yang sering digunakan adalahs Pangkemitan, sebagal pos jaga bagi rumah pemimpin adat

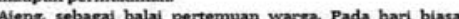
Ajeng sebagad balai pertemuan warga. Pada hari biasa Saung lisunge kerap digunakan untuk menumbuk padi bagi
ibu rumah taneza dí permukiman.

- Bangunan fasilitas umum lain pada umumnya digunakan pada saat pelaksanasun ritual adat misalnya poryogumen sebagal dapur umum dan leste si jimat sebagal lumbung
padi komunal.

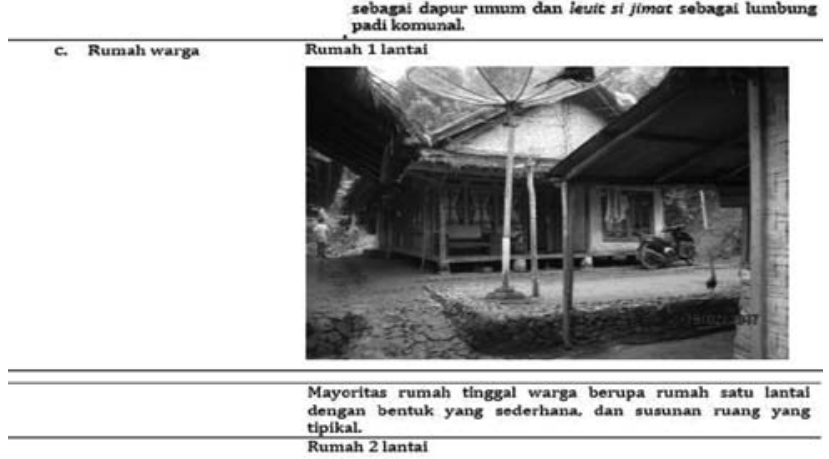
umah 2 lantai

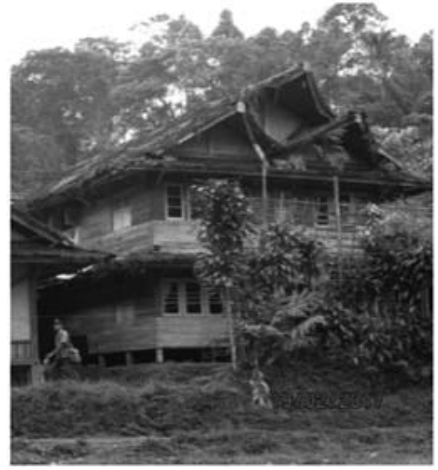

Pada kawasan permuklman, hanya terdapat 4 banguna radislonal yang bertingkat 2 . Secara struktur dan material yans digunakan. sama dengan rumah warga lainnya, yakn megg 


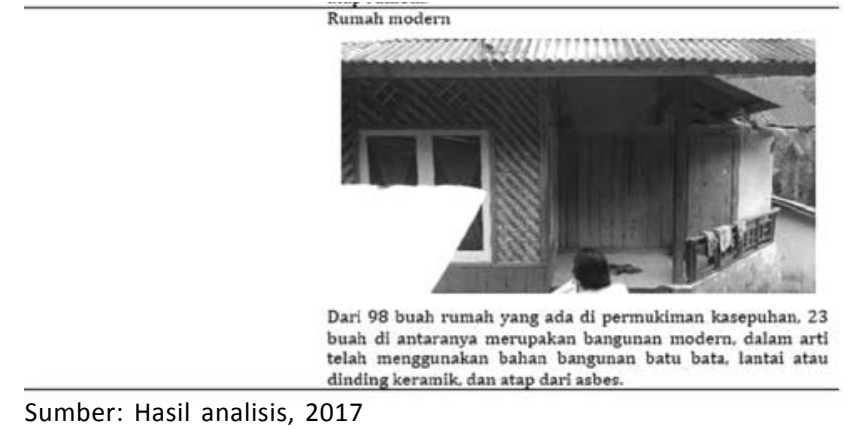

\section{Morfologi Pada Kawasan Permukiman Sinar Resmi}

Seiring dengan perubahan jaman dan sistem pengetahuan masyarakat, ada beberapa perubahan yang terjadi di kawasan permukiman yang dikaji dengan teori milik Habraken.

\section{Sistem Spasial}

Meskipun telah menggunakan sistem konstruksi yang modern, namun secara tata ruang bagi warga yang berasal dari kasepuhan tidak menghilangkan ruang penyimpanan beras (padaringan) dan tungku (hawu). Hal ini dapat diartikan bahwa mereka tetap mempercayai nilai kesakralan dari padi bagi kehidupannya. sebagai pendatang di desa tersebut. Bentuk pintu dan jendela tidak terlalu banyak berbeda dengan bangunan tradisional, karena seperti halnya pada bangunan tradisional, yang juga menggunakan bahan kaca untuk jendela. Bentuk atap pada beberapa rumah juga mengalami perubahan dari atap pelana menjadi atap perisai.

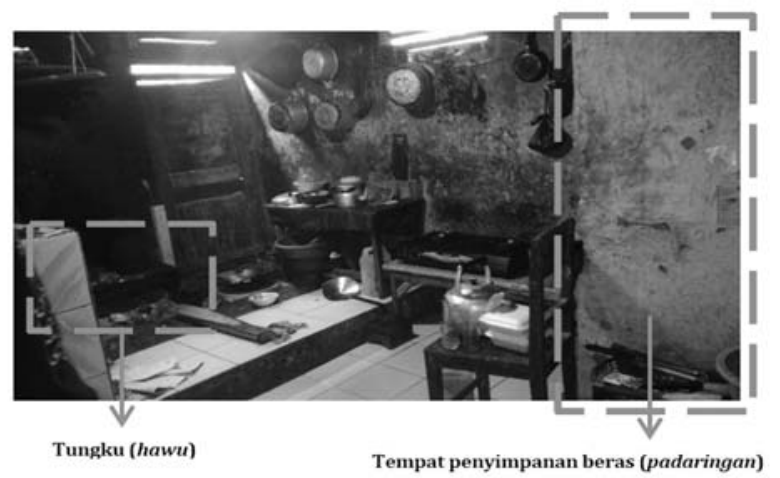

Gambar 14. Elemen tungku dan tempat penyimpanan beras pada bangunan modern (Sumber: Dokumentasi pribadi, 2017)

\section{Sistem Model}

Dari 98 buah rumah yang ada di permukiman, terdapat 23 rumah yang menggunakan konstruksi modern menggunakan dinding bata dan atap asbes sehingga terkesan memilki langgam modern meskipun tampilan bangunannya sederhana. Hal ini selain dikarenakan perubahan keyakinan dari kepercayaan terhadap tradisi, juga karena masuknya penduduk luar Desa Sirnaresmi

3. Sistem Fisik

Rumah tinggal di kawasan permukiman kasepuhan yang telah menggunakan bahan selain yang telah ditentukan, dapat dikatakan sebagai bangunan yang modern. Perubahan ini berupa berubahnya material bangunan yang digunakan Sistem fisik berkaitan dengan tampilan bangunan secara fisik, yang dapat dilihat salah satunya melalui penggunaan material. Bangunan pada kawasan permukiman pada rumah, yakni menggunakan dinding batu bata, bahan keramik untuk dinding dan lantai serta atap asbes.

\section{KESIMPULAN}

Tipomorfologi kawasan permukiman Kasepuhan Sinar Resmi dapat dilihat dari konteks makro, meso, maupun mikro. Keadaan geografis kawasan permukiman yang berkontur sangat berpengaruh terhadap pola tata massa bangunan. Pada skala makro, elemen pembentuk permukiman adalah faktor alam, naungan, sirkulasi, manusia dan masyarakat. Sedangkan pada skala meso, elemen pembentuk permukiman adalah tata massa bangunan rumah tinggal dan fasilitas umum. Pada skala mikro, elemen yang dikaji adalah bentuk dan tata ruang dalam bangunan. Pada permukiman ini terdapat empat jenis bangunan, yakni bangunan rumah tinggal pemimpin adat, bangunan rumah tinggal tradisonal satu lantai, bangunan rumah tinggal tradisional dua lantai, serta bangunan 


\section{Tipomorfologi Permukiman Kasepuhan Sinar Resmi, Kabupaten Sukabumi}

Sari Mawaddahni

modern. Pola permukiman memusat dengan rumah tinggal pemimpin adat sebagai orientasi arah hadap bangunan, serta pola permukiman linier bagi bangunan yang berada di tepi jalan. Dengan adanya kesamaan bentuk dan material bangunan, tidak terjadi kesenjangan sosial di antara masyarakat. Kondisi bangunan pada umumnya masih terawat. Akan tetapi bagaimanapun juga, masih terdapat perbedaan tingkat kesejahteraan penghuni ditinjau dari fisik bangunannya.

Tipologi dan morfologi kawasan dan hunian sangat dipengaruhi oleh sosial budaya masyarakat yang ada pada permukiman ini. Budaya yang berdasar pada kehidupan rural agraris masih dipegang teguh oleh masyarakat kasepuhan. Hal ini menjadikan kawasan permukiman kasepuhan Sinar Resmi memiliki Genius Loci atau kekhasan dibandingkan dengan kawasan permukiman lain. akan tetapi dengan keterbatasan ekonomi masyarakat, dikhawatirkan dapat merubah pola pikir dan kebudayaannya, sehingga dapat melunturkan nilai tradisi yang telah dibangun oleh leluhur selama beberapa generasi.

Dengan adanya kajian terhadap tipologi dan morfologi kawasan permukiman kasepuhan Sinar Resmi, diharapkan dapat menjadi bahan pertimbangan bagi pihak pemerintah baik pusat atau daerah untuk melindungi kawasan permukiman kasepuhan Sinar Resmi sebagai cadar budaya yang dilindungi keberadaannya. Keberadaan permukiman ini juga menjadi khasanah bagi keberagaman budaya Indonesia dengan nilai-nilai budaya yang luhur sehingga patut dilestarikan.

\section{Referensi}

${ }^{1}$ Nuryanto \& Isep, Machpudin. 2008. Kajian Pola Kampung Dan Rumah Tinggal Warga Kasepuhan Kesatuan Adat Banten Kidul di Sukabumi SelatanJawa Barat. Artikel Hasil Penelitian Arsitektur Tradisional Sunda. Bandung: Universitas Pendidikan Indonesia.

${ }^{2}$ Pitana, Titis S. 2007. Reproduksi Simbolik Arsitektur Tradisional Jawa: Memahami Ruang Hidup Mate- rial Manusia Jawa. GEMA TEKNIK. Nomor 2/ Tahun X: $126-133$.

${ }^{3}$ Sasongko, I. 2005. Pembentukan Struktur Ruang Permukiman Berbasis Budaya (Studi Kasus: Desa Puyung - Lombok Tengah). Dimensi Teknik Arsitektur. 33(1): 1 - 8.

${ }^{4}$ Kusdiwanggo, S. 2016. Konsep Pola Spasial Permukiman di Kasepuhan Ciptagelar. Jurnal Permukiman. 11(1): 43-56.

${ }^{5}$ Nurfansyah. 2012. Tipologi Kawasan Jalan Pageran Antasari Banjarmasin. INFO TEKNIK. 13(1): 5056.

${ }^{6}$ Punuh, Claudia Susana. 2014. Genius Loci Kampung Los Di Kelurahan Malalayang I Timur Manado. Sabua. 5(2): 261-267.

${ }^{7}$ Mentayani, Ira \& Dila Nadya, Andini. 2007. Tipologi dan Morfologi Arsitektur Suku Banjar di Kal-Sel. INFO -TEKNIK . 8(2): 114-122.

${ }^{8}$ Darvill, Timothy. 2003. The Concise Oxford Dictionary of Archaeology. UK: Oxford University Press.

${ }^{9}$ Bandini, Micha. 1984. Typology as A Form of Convention. AA Files. 6: 73-82. http://www.jstor.org/ stable/29543402. [diakses 12 Maret 2017].

${ }^{10}$ Ramadanta, Asyra. 2010. Kajian Tipologi Dalam Pembentukan Karakter Visual Dan Struktur Kawasan (Studi Kasus: Kawasan Ijen, Malang). Jurnal SMARTek. 8 (2): 130-142.

${ }^{11}$ Suharjanto, Gatot. 2011. Bahan Bangunan Dalam Peradaban Manusia: Sebuah Tinjauan Dalam Sejarah Peradaban Manusia. HUMANIORA. 2 (1): 814-825.

${ }^{12}$ Iskandar, 2004. Tradisionalitas Dan Modernitas Tipologi Arsitektur Masjid. Dimensi Teknik Arsitektur. 32(2): 110-118.

${ }^{13}$ Setyabudi, I., Antariksa, Nugroho, A. M. 2012. Tipologi Dan Morfologi Arsitektur Rumah Jengki di Kota Malang Dan Lawang. Arsitektur e-Journal. 5 (1): 3246.

${ }^{14}$ Doxiadis, C.A. 1968. Ekistic: an Introduction to the Science of Human Settlements. London: Hutchinson of London.

${ }^{15}$ Antariksa. 2011. Pola Permukiman Tradisional. https:// www.academia.edu/ $7762405 /$ POL A PERMUKIMAN_TRADISIO NAL. (diakses $2 \overline{9}$ Desember 2016). 
